\title{
As novas comunidades na pluralidade missionária da nova paróquia
}

\author{
The new communities in plurality \\ missionary of new parish
}

\author{
Denilson Geraldo \\ Rodrigo Fernando Alves
}

\section{Resumo}

O século XX, marcado pelo Concílio Vaticano II, trouxe um florescimento da pastoral da Igreja e da ação evangelizadora. As Novas Comunidades (NC) e os Novos Movimentos Eclesiais (NME) irromperam como força da presença dos leigos para a transformação do mundo e a renovação da Igreja. Nesses fenômenos, os batizados se unem em associações de fiéis, vivendo um determinado carisma do Espírito em comunidades orantes e fraternas. Da mesma forma, a paróquia reafirma-se como instituição fundamental para a presença eclesial, buscando ser uma Nova Paróquia a partir da opção pela dimensão comunitária e a missão urbana - ser uma Igreja "em saída" nas palavras do Papa Francisco. O grande desafio parece ser integrar as Novas Comunidades nas atividades missionárias da Nova Paróquia, numa integração que se refere tanto à participação efetiva em Conselhos, ao bom relacionamento que aproveita as virtudes mútuas e à contemplação das NC nos planos de pastoral.

Palavras-chave: Nova Paróquia. Novas comunidades. Novos movimentos eclesiais. Missão.

\begin{abstract}
The twentieth century marked by the Second Vatican Council brought a flowering of pastoral of the Church and evangelization. New Communities
\end{abstract}


(NC) and the New Ecclesial Movements (NEM) broke out as a force of the presence of the laity to transform the world and the renewal of the Church. In these phenomena, the lay faithful are united in associations, living a certain charisma of the Spirit in prayerful and fraternal communities. Similarly, the parish is reaffirmed as a fundamental institution for the ecclesial presence, seeking to be a New Parish from the choice of the Community dimension and the urban mission - to be a Church "in output" in the words of Pope Francis. The challenge seems to be to integrate the new communities in the missionary activities of the New Parish, an integration that refers both to effective participation in councils, the good relationship that leverages the mutual virtues and contemplation of the $\mathrm{NC}$ in the pastoral plans.

Keywords: New Parish. New communities. New ecclesial movements. Mission.

\section{Introdução}

Após o Vaticano II a Igreja é convocada a unir forças, integrar realidades e formar os batizados para uma atividade que a faça mais parecida como vigor de seus inícios. As reflexões desde então trazem apelos para uma maior movimentação de todo o seu ser (totius esse), de todo o corpo eclesial. Movimentos missionários, atos de uma Igreja "em saída", em oposição a uma realidade acomodada e defensiva. E para que isso ocorra há um chamamento para o que também floresceu junto à convocação de mudanças: os Novos Movimentos Eclesiais e as Novas Comunidades.

O presente artigo tem o objetivo de, num primeiro momento, trazer a definição dos conceitos recentes sobre o que são os Novos Movimentos Eclesiais e as Novas Comunidades, as atividades missionárias e a "nova paróquia"; para, por fim, relacionar os três assuntos em vista do envolvimento das Novas Comunidades e dos Novos Movimentos Eclesiais nas atividades missionárias da "nova paróquia".

\section{Pontuando os Conceitos}

\subsection{As Novas Comunidades}

Assim como na lógica matemática um conjunto se insere em outro conjunto numérico mais genérico e abrangente, podemos dizer que as Novas Comunidades (NC daqui em diante) se inserem dentro do universo dos 
Novos Movimentos Eclesiais (NME daqui em diante) na Igreja. Sendo assim, primeiramente deve-se pormenorizar o conceito mais amplo: os Novos Movimentos Eclesiais (NME).

Os NME não são uma exclusividade absoluta do século XX, mas, como explica Hans Urs von Balthasar, são como que "respostas" que o Espírito Santo outorga às perguntas mais urgentes da História Universal da Igreja - oportunidades (kairoi) tais como a aparição de um grande Santo reformador ou de uma nova missão eclesial ${ }^{1}$. No século III, com o aprofundamento da cisão entre clero (kleros) e leigos (laikos), por diversos momentos a estrutura clerical esteve à beira do fracasso. Foram períodos intensos como o da crise moral da vida religiosa e do papado no obscuro século IX, como o "exílio" de Avignon e a decadência do Papa Alexandre VI, etc. Em momentos delicados como esses o Espírito suscita reformas importantes na Igreja, que normalmente tem como protagonistas não apenas membros da hierarquia, mas religiosos e leigos. Dois exemplos disso são Santa Catarina de Sena e São Francisco de Assis.

Desse modo, podemos elencar como uma primeira característica dos NME o apostolado dos leigos. Como escreve Antônio José de Almeida, se na Idade Média o leigo mais perfeito era aquele mais próximo da vida monástica (com uma vida ascética e meditativa $)^{2}$, no século $\mathrm{XX}$ os leigos são chamados a "não ficarem encerrados em si mesmos" e exercerem um apostolado fecundo na terra ${ }^{3}$.

Outra característica desses NME é o seu empenho evangelizador diante dos "sinais dos tempos". Os diversos grupos como Focolari, Equipes de Nossa Senhora, Renovação Carismática Católica, Neocatecumenato, Movimento dos Cursilhos de Cristandade ou Movimento de Schönstatt, todos eles têm uma mensagem particular de esperança e transformação para compartilhar com um mundo em crise ${ }^{4}$. Outro traço dos NME é o modo como cada um deles incide com mais força sobre um aspecto da evangelização

\footnotetext{
${ }^{1}$ BALTHASAR, Hans Urs von. Teologia de la Historia. Trad. de José Maria Valverde. 2 ed. Madrid: Ed. Guadarrama, 1964, pp. 148-149.

${ }^{2} \mathrm{Na}$ Idade Média o leigo era considerado como que um cristão de segunda categoria, tanto que se afirmava que existiam "dois gêneros de cristãos" (duo sunt genera christianorum), um mais próximo de Deus (clero) e outro menos (leigos). In: ALMEIDA, Antônio José de. Leigos em quê? Uma abordagem histórica. São Paulo: Paulinas, 2006, p. 99.

${ }^{3}$ JOÃO XXIII. Princeps Pastorum, n. 37.

${ }^{4}$ FERREIRA, Wagner. As Novas Comunidades no Contexto Sociocultural Contemporâneo. São Paulo: Canção Nova, 2011, p. 43.
} 
(família, política, moral, liturgia, devoção, ecumenismo, catequese, Bíblia ${ }^{5}$. $\mathrm{O}$ aspecto sublinhado vai depender do carisma que o Espírito suscitou no Movimento Eclesial em questão. Finalmente, os NME são per se uma realidade agregativa, comunitária. Esse termo foi usado pelo Papa João Paulo II na Exortação Apostólica Christifideles laici para tratar dos Movimentos Eclesiais. Segundo ele, os Padres Sinodais do Pós-Concílio almejavam que os NME desembocassem numa "autêntica" práxis eclesial referente

aos ministérios e aos serviços eclesiais confiados ou que deverão confiar-se aos fiéis leigos, a difusão e o crescimento de novos «movimentos» ao lado de outras formas agregativas de leigos, o lugar e a função da mulher tanto na Igreja como na sociedade 6 .

A ligação que João Paulo II faz não é sem razão: os NME não fazem despontar somente o apostolado do laicato, mas também sublinham a ação e a importância da mulher na evangelização. De qualquer forma, eles possuem um caráter agregativo e associativo fundamental. O Concílio apoia essa característica agremiadora, comunitária, exortando os fiéis leigos a atuarem na sociedade de preferência de forma associativa ${ }^{7}$ :

O apostolado em associação é de grande importância também porque, nas comunidades eclesiais e nos vários meios, o apostolado exige com frequência ser realizado mediante a ação comum. As associações criadas para a ação apostólica comum fortalecem os seus membros e formam-nos para o apostolado. Além disso, distribuem ordenadamente e orientam o seu trabalho apostólico, de modo que se podem esperar daí frutos muito mais abundantes do que se agisse cada um por sua conta. ${ }^{8}$

Uma última característica crucial dos NME é que em todos esses organismos deve circular uma seiva comum: a escuta da Palavra, a vida dos sacramentos e o ágape (a caridade). Essa tríade é o elemento vinculante fundamental de todos os $\mathrm{NME}^{9}$.

${ }^{5}$ O Capítulo III do Decreto Apostolicam Actuositatem distingue cinco "campos maiores" para o apostolado dos leigos: a Igreja, a familia, os jovens, a sociedade e o bem comum (nacional ou internacional).

${ }^{6}$ JOÃO PAULO II. Chritifideles Laici, n. 2.

${ }^{7}$ Embora o apostolado individual dos leigos seja chamado de "necessário" no Capítulo IV do Decreto Apostolicam Actuositatem, a ênfase recai sobre o modo associado de apostolado.

${ }^{8}$ CONCÍLIO VATICANO II. Decreto Apostolicam Actuositatem, n. 18.

${ }^{9}$ PAULO VI. Evangelii Nuntiandi, n. 58. 
Assim, resumidamente, pudemos distinguir algumas características básicas dos NME: o apostolado dos leigos, o empenho evangelizador diante dos sinais dos tempos (com ênfase em um ou mais aspectos da evangelização/depende do Carisma), sua realidade agregativa/comunitária e os três elementos vitais de cada NME: a escuta da Palavra, a vida dos sacramentos e $\mathrm{o}$ ágape (caridade).

As NC possuem em si os traços elencados acima, mas contém algumas diferenças fundamentais. Em primeiro lugar, há uma diferença de natureza tipológica entre os NME e as NC, que, na verdade, é a diferença básica entre duas estruturas: os Movimentos e as Novas Comunidades. Basicamente, os Movimentos surgem com uma liderança carismática e se desenvolvem em torno de uma ideia-força ${ }^{10}$, de um programa que impele à ação, podendo subdividir-se em vários grupos fiéis a esse espírito. Enquanto que as NC são movimentos eclesiais que se estruturam como grupos que fazem o compromisso de vida com um carisma ligado, geralmente, à espiritualidade da Renovação Carismática Católica. Como isso acontece? Ora, inicialmente

forma-se um grupo de oração, de caráter mais espiritual e espontâneo, com o objetivo principal de viver a proposta carismática do próprio movimento. Com o passar do tempo, com o amadurecimento da comunhão entre os participantes e o despertar de uma forte liderança (...), discerne-se o chamado à constituição de uma comunidade de vida, muito semelhante ao estilo de vida comunitária das congregações religiosas, com o objetivo de cultivar mais intensamente aquela espiritualidade carismática e a própria vida cristã, tendo como protótipo as comunidades cristãs da Igreja primitiva. ${ }^{11}$

Podemos dizer que as NC difundiram-se bastante e estão bem pulverizadas no contexto brasileiro, citando apenas algumas mais amplas, tais como a Comunidade Canção Nova e a Comunidade Católica Shalom. Entrementes, é importante tecer algumas considerações ainda acerca das NC.

Em primeiro lugar, é curioso o paradoxo que existe na identidade das NC. Como pudemos ler na definição acima (elaborada na tese de doutoramento do Formador Geral da Comunidade Canção Nova na Academia Alfonsiana de Roma), as NC constituem uma "comunidade de vida, muito semelhante ao estilo

${ }^{10}$ CAMISASCA, Massimo; VITALI, Maurizio. I movimenti nella Chiesa negli anni'80. Atti del $1^{\circ}$ Convegno Internazionale (Roma, 23-27 settembre 1981). Milano: Jaca Book, 1982, p. 167.

${ }^{11}$ FERREIRA, W. As novas comunidades no contexto sociocultural contemporâneo. São Paulo: Canção Nova, 2011, p. 54. 
de vida comunitária das congregações religiosas" (religious life). Contudo, quando tais comunidades são aprovadas pelo bispo diocesano, a Igreja as classifica com um título civil e canônico ${ }^{12}$ : associação pública ou associação privada de fiéi ${ }^{13}$. Isso mostra a novidade da matéria para a Igreja ao situar as Novas Comunidades em seu interior, procurando diferenciá-las das Congregações e Ordens Religiosas, apesar da poderosa conexão entre ambas.

Em segundo lugar, outro dado da definição anterior revela-se importante. Não obstante as Novas Comunidades possuam uma espiritualidade carismática ligada à RCC (Renovação Carismática Católica), o protótipo (proto-typos = primeiro modelo) das NC são as comunidades cristãs da Igreja primitiva. Nisso temos não apenas uma fundamentação bíblica para a vida comunitária de partilha dos bens e da missão, mas uma característica que perpassa o movimento comunitário de renovação da Igreja no Concílio Vaticano II: a volta às fontes cristãs ${ }^{14}$, atualizando a eficácia daquele primeiro Pentecostes em um mundo em crise.

\subsection{As atividades missionárias}

A Missão Evangelizadora perpassa a história da Igreja desde Paulo de Tarso até as missões no período da Renascença com a descoberta do "Novo Mundo", passando pelo Concílio Vaticano II, a Evangelii Nuntiandi e o impulso de João Paulo II na Redemptoris Missio. Por isso, é fundamental delimitarmos a temática, situando as atividades missionárias em conexão com o contexto atual da Igreja e do Mundo. Afinal, hoje a concepção de "Missão" é cada vez mais complexa e polissêmica, indo "do simples anúncio à presença midiática, da catequese paroquial à nova evangelização", entre outros ${ }^{15}$.

A grande referência contemporânea do nosso contexto latino-americano acerca da Missão é o Documento de Aparecida, fruto da V Conferência do CELAM. Ao lado do Documento de Aparecida (ou acima, se seguirmos a ordem

\footnotetext{
${ }^{12}$ Cânon 299 (parágrafo primeiro) do Código de Direito Canônico: "Por acordo privado, os fiéis têm o direito de constituir associações, para a obtenção dos fins mencionados no cân. $298, \S 1$, salva a prescrição do cân. 301". O parágrafo seguinte (§2) afirma que o nome próprio dessas associações é "Associações privadas". In: CÓDIGO DE DIREITO CANÔNICO. Vaticano: Libreria Editrice Vaticana, 1983.

${ }^{13}$ Cânon 299.

${ }^{14}$ Yves Congar prefere falar de um re-sourcemente. Nas palavras dele: "mais que um retorno às fontes, que certamente se dava, se trata de uma ascensão em nosso tempo da fonte e da seiva" (Tradução nossa). In: CONGAR, Yves M.-J. El Espiritu Santo. Barcelona: Herder, 1991, p. 355.

${ }^{15}$ MAÇANEIRO, Marcial. "Missão no Plural”. Teologia em Questão 18 (2010), p. 7.
} 
do universal para o particular) temos como referência a Exortação Apostólica Evangelii Gaudium do Papa Francisco (que felizmente participou ativamente da redação do Documento de Aparecida). Encarnando essa proposta para o contexto brasileiro não se pode dispensar a leitura e reflexão sobre o último documento lançado pela CNBB acerca da Paróquia (Documento 100 - Comunidade de Comunidades: uma Nova Paróquia). É nesse campo específico das atividades missionárias no seio das paróquias e comunidades que o caminho é proposto.

Se antes a Missão era vista apenas como Missão Ad Gentes, hoje a linguagem da Igreja fala de Missão ad intra, evidenciando a proposta da Nova Evangelização do Ocidente por João Paulo II (a Europa fria que precisa experimentar o calor do Evangelho). Por isso o Documento de Aparecida conjuga os dois vocábulos juntos: Discípulos-Missionários ${ }^{16}$.

A Igreja é impelida a manifestar-se com "novo ardor missionário", como "mãe que vai ao encontro, uma casa acolhedora, uma escola permanente de comunhão missionária" 17 . É uma Igreja "em saída", que vai ao encontro dos seus filhos e filhas antecipando-se (o Papa Francisco usa o neologismo "primeirear"18). É importante frisar o vocábulo "Encontro" porque ele fornece a tônica e o sentido da Missão, que é o Encontro da Igreja com o Mundo, de Jesus Cristo com todas as pessoas e Povos. Como escreve Julio A. Ramos Guerreira,

se a Igreja está constituída pela Missão, tem que romper uma tradição que baseia a ação eclesial somente no culto, tem que estabelecer o diálogo, tem que aprender com o mundo a eficácia em seus modos de lidar com as questões, tem que aprender a importância que os grupos sociais exercem sobre os indivíduos, tem que abrir suas fronteiras e reavivar suas forças missionárias. ${ }^{19}$

Quais as atividades missionárias da Nova Paróquia, da Paróquia "em saída"? A resposta é "todas": as atividades pastorais (familiar, juventude, educação, catequese) ${ }^{20}$, sociais (que atendem os pobres, excluídos, enfermos,

\footnotetext{
${ }^{16}$ CELAM. Documento de Aparecida. Trad. de Luiz Alexandre Solano Rossi. 5 ed. São Paulo: Paulus, 2008, p. 21.

${ }^{17}$ Idem, p. 166.

${ }^{18}$ FRANCISCO. Evangelii Gaudium, n. 24.

${ }^{19}$ GUERREIRA, Julio A. Ramos. Teología Pastoral. Serie de Manuales de Teología "Sapientia Fidei”. Madrid: Biblioteca de Autores Cristianos, 1995, p. 50.

${ }^{20}$ Chama a atenção o fato de o Documento de Aparecida abordar muitas pastorais eclesiais, mas não a litúrgica (a dimensão do culto). Porém, o sentido dessa desconsideração pode ser justamente a preocupação social da Igreja Latino-Americana com seu contexto. Ainda assim,
} 
migrantes, doentes, dependentes de drogas, detidos), políticas, ecológicas, urbanas. O "ser missionário" deve ser latente e patente em todas as atividades eclesiais. De maneira especial, o Documento de Aparecida sublinha a necessidade de uma "formação permanente" da paróquia para a assunção da Missão, principalmente na área da Catequese ${ }^{21}$.

O grande desafio das atividades missionárias hoje talvez seja a Missão da Pastoral Urbana, tanto nas pequenas como, principalmente, nas grandes cidades. As cidades têm origem na Idade Média, em um processo sem planejamento. As cidades nascem e crescem de forma desorganizada, pois seus habitantes não planejavam formar uma cidade; apenas pretendiam formar comunidades que fizessem frente aos senhores feudais ${ }^{22}$. Esse crescimento desordenado, sem planejamento, trará graves consequências sociais e sanitárias no futuro.

Diante da complexidade da cidade e de seus problemas, João Batista Libânio propõe três perspectivas para uma Pastoral Urbana missionária ${ }^{23}$. Primeiro, a Presença Pública da Igreja: a pastoral da Igreja é chamada a situar-se diante das injustiças e inumanidades vistas nas cidades com uma missão crítico-profética, que não apenas denuncia os problemas e males como também incrementa as ações positivas da parte sadia da sociedade.

Em segundo lugar, a Espiritualidade para o cristão: as paróquias não conseguem acompanhar o crescimento demográfico e despersonalizaram-se. Os fiéis caem no anonimato, e por isso sentem solidão e isolamento, com o incremento das "periferias humanas" ${ }^{2}$. Libânio afirma que vivemos a tendência do Mega nas cidades (megaló-polis, multi-nacionais, internacionalização da economia) $)^{25}$, mas que a espiritualidade da missão urbana deve

hoje também percebemos iniciativas de uma liturgia "em saída". Um exemplo disso é a nova tradição do Papa Francisco de celebrar o lava-pés não na Basílica de São João de Latrão, mas em uma prisão romana.

${ }^{21}$ CELAM, 2008, p. 137.

${ }^{22}$ Podemos estimar que entre os anos 1000 e 1328 a população do Reino da França duplicou (de 6 milhões de habitantes para 13,5 milhões). In: LE GOFF, Jacques. O apogeu da Cidade Medieval. Trad. de Antônio de Pádua Danesi. São Paulo: Martins Fontes, 1992, p. 5.

${ }^{23}$ LIBÂNIO, João Batista. "Missão da Igreja na cidade - pastoral urbana". In: FERNANDEZ, José Cobo (Org.). A presença da Igreja na cidade II: Novos desafios, novas abordagens. Petrópolis: Vozes, 1997, p. 38.

${ }^{24}$ FRANCISCO. Evangelii Gaudium, n. 46.

${ }^{25}$ FERNANDEZ, J. G. A presença da Igreja na cidade II: Novos desafios, novas abordagens. Petrópolis: Vozes, 1997, p. 44. 
sempre buscar a pessoa, os rostos das gentes. Nesse sentido, a visitação é um caminho de personalização cuja raiz é o próprio Evangelho ${ }^{26}$.

Por fim, a Igreja como rede de comunidades: o Encontro (Kerygma) que a Missão tanto almeja (seja no papel ativo de ir ao encontro ou na abertura de deixar-se encontrar) sempre visa à comunhão (Jesus-Comunidade-Pessoa). Principalmente nas cidades com seus tantos desencontros: "É urgente ir ao encontro daqueles que se afastaram da comunidade ou dos que a concebem apenas como uma referência para serviços religiosos. (...) Se forem bem acolhidos poderão retornar ou ingressar na vida comunitária"27. A estrutura paroquial, nascida em outros períodos e contextos (rurais, menos povoados) é desafiada a adaptar-se a esse novo cenário.

Finalizando, a postura das atividades missionárias diante dos novos contextos socioculturais, tem a marca da profecia, superando o fechamento e o medo, com novos métodos e linguagens, embasadas em um Plano Urbano orgânico/integrado de Pastoral. Outras experiências válidas para a Pastoral Urbana são: "a renovação das paróquias, setorização, novos ministérios, novas associações, grupos, comunidades e movimentos" ${ }^{28}$.

\subsection{A Nova Paróquia}

A instituição paroquial é uma instituição milenar que nasceu no século IV e subsiste até os dias atuais, sendo ainda bastante consistente não obstante todas as profundas mudanças históricas que ocorreram. Como escreve o Papa Francisco na Exortação Apostólica Evangelii Gaudium, "a paróquia não é uma estrutura caduca; precisamente porque possui uma grande plasticidade" 29 . De fato, a paróquia nasce da adaptação da ação pastoral urbana às igrejas rurais recém-criadas, sendo, portanto, uma instituição que per se é vocacionada a encarnar-se na realidade. O próprio termo paróquia é derivado do grego paroikia e tinha dois significados: "avizinhamento, ser vizinho" e "comuni-

\footnotetext{
${ }^{26}$ A visitação abre a comunidade para fora de si, evitando que ela se torne - nas palavras de Pagola - uma "ilhota”. In: PAGOLA, José Antonio. Acción pastoral para una nueva evangelización. Santander: Sal Terrae, 1991, p. 54.

${ }^{27} \mathrm{CNBB}$, Comunidade de comunidades: uma nova paróquia. Documento 100. Brasília: Edições CNBB, 2014, n. 318.

${ }^{28}$ SOUZA, Cirlene Cristina de. "Cidade-gente: desafios para a missão da Pastoral Urbana". Teologia em Questão 18 (2010), p. 20.

${ }^{29}$ FRANCISCO. Evangelii Gaudium, n. 28.
} 
dade peregrina, de estrangeiros, forasteiros" ${ }^{\prime 30}$. Assim, em suas origens a paróquia já possuía em si uma carga preciosa que mostrava tanto que os cristãos são peregrinos neste mundo como, também, que a Igreja deve estar no meio do povo, vivendo "no meio das casas dos seus filhos e das suas filhas"31.

Com o advento da christianitas (cristandade), a paróquia assumiu para si uma estrutura monárquica e régia (imagem da Igreja como Ecclesia regina) ${ }^{32}$. A pastoral existente nesse modelo ficou sacramentalista e judicial. As paróquias estavam acomodadas, enquanto se multiplicava o número dos não-crentes (pagãos), a ponto de dois sacerdotes publicarem um texto de grande repercussão no seio da Igreja: La France, pays de mission ${ }^{33}$ Como aquele que era considerado o "grande país católico" tornou-se "terra pagã de missão"?

Atualmente, a paróquia aos poucos procura superar o modelo tradicionalista-sacramentalista, vivendo outros paradigmas na pastoral: a evangelização, a missão, o acento no aspecto comunitário e a ênfase em uma práxis libertadora.

A Nova Paróquia, comunidade de comunidades, "é presença eclesial no território, âmbito para a escuta da Palavra, o crescimento da vida cristã, o diálogo, o anúncio, a caridade generosa, a adoração e a celebração"34. Ela é fruto da superação da linguagem imperial - kyriárquica na Igreja (ex.: Palácio episcopal, Magna Hóstia) para uma linguagem mais próxima das primeiras comunidades cristãs (a Igreja como Casa - a domus ecclesiae ${ }^{35}$-, como "Mãe de coração aberto" e "casa aberta do Pai" ${ }^{36}$ ). A Nova Paróquia é, sobretudo, aquela que é capaz de renovar-se (converter-se) diante dos novos contextos e ser um ponto de convergência e irradiação de comunidades:

A nova paróquia propõe como objetivo tornar-se uma base de integração para a formação comunitária. O fim de toda pastoral é e sempre foi a salvação

${ }^{30}$ FLORISTÁN, Casiano. Para compreender La Parroquia. Estella: Editorial Verbo Divino, 1998, p. 6.

${ }^{31}$ FRANCISCO. Evangelii Gaudium, n. 28.

${ }^{32}$ BRIGHENTI, Agenor. A pastoral dá o que pensar: a inteligência da prática transformadora da fé. Manual Básico de Teologia Pastoral. São Paulo: Paulinas, 2006, p. 35.

${ }_{33}$ DANIEL, Yvan; GODIN, Henri. La France, pays de mission? Lyon: Les Éditions de l'Abeille, 1943.

${ }^{34}$ FRANCISCO. Evangelii Gaudium, n. 28.

35 SZENTMÁRTONI, Mihály. Introdução à Teologia Pastoral. Trad. de Orlando Soares Moreira. 3 ed. São Paulo: Loyola, 2014, p. 57.

${ }^{36}$ Imagens utilizadas pelo Papa Francisco, muito mais próximas da calorosa realidade familiar do que de estruturas políticas (tal como a monarquia). In: FRANCISCO. Evangelii Gaudium, n. 46-49. 
dos homens, e todas as estruturas eclesiásticas servem a essa finalidade. A paróquia é a unidade de base dentro da qual se edifica a comunidade que não é fim em si mesma, mas é comunidade para os outros. ${ }^{37}$

O Documento 100 da CNBB, que aborda primordialmente a temática da Nova Paróquia, expõe treze características para que a Paróquia se converta em "comunidade de comunidades" 38 . De forma sintética, elencamos a seguir:

- Formar pequenas comunidades; Investir na meditação da Palavra de Deus com Métodos apropriados (tal como a Leitura Orante); Celebrar a Eucaristia e tê-la como ponto de unidade das comunidades da paróquia; Organizar retiros; Estabelecer o CPP (Conselho de Pastoral Paroquial) e o CAEP (Conselho de Assuntos Econômicos) para garantir a comunhão e a participação; Valorizar o laicato e a formação dos ministérios leigos; Acolhida dos afastados na comunidade, como expressão da missão; Viver a caridade e opção preferencial pelos pobres; Que a Igreja matriz e as outras igrejas sejam centros de irradiação de espiritualidade; Dar maior atenção aos condomínios e conjuntos de residências populares; Garantir a comunhão com a totalidade da Diocese; Utilizar os recursos da mídia para aprofundar o relacionamento da paróquia com as pessoas; Ser uma Igreja "em saída", missionária.

Desse quadro básico de objetivos da Nova Paróquia, encontramos alguns princípios norteadores. O primeiro é a Formação. A Conferência de Aparecida insiste na conexão entre "formação permanente" e "conversão missionária". Algumas características elencadas acima evidenciam direta ou indiretamente a relevância de uma paróquia onde a formação seja constante, tenha como destinatário essencial os leigos (laicato) e tenha um enfoque bíblico e voltado à espiritualidade ${ }^{39}$. Por aqui cabe uma diferença entre "formar os leigos" e formar comunidades", embora uma sinergia perpasse ambos. Formar os leigos significa formá-los no conteúdo da fé (Credo - Confessio fidei) e da vida ${ }^{40}$. Implica estudo e espiritualidade, entrar no Mistério do Amor Salvador da Trindade - narratio amoris ${ }^{41}$. Formar comunidades exige planejamento, esforço e consciência cristã e eclesial por parte do clero e do laicato, cujo primeiro

${ }^{37}$ SZENTMÁRTONI, 2014, p. 57.

${ }^{38}$ CNBB, Documento 100, n. 319.

${ }^{39}$ CELAM, 2008, p. 169.

${ }^{40} \mathrm{O}$ conhecimento da realidade e do contexto sociocultural também entra nessa dimensão da Formação (a lente científica/sociológica de leitura). Libânio expõe a importancia desse conhecimento para a Pastoral Urbana. In: FERNANDEZ, 1997, p. 37.

${ }^{41}$ FORTE, Bruno. As Cores do Amor. Trad. de Silva Debetto C. Reis. São Paulo: Loyola, 2013, p. 67. 
passo é o conhecimento e amor de Deus e da missão da Igreja.

Outro ponto de convergência que reaparece nessa lista é aquela tríade que também é cara aos NME e NC: a escuta da Palavra, a Eucaristia (vida sacramental) e o ágape (caridade). O ágape é dom que não passa, como conclui Paulo no hino de 1Cor. A paróquia tem como tarefa criar, formar e alimentar as suas comunidades com esse fundamento. Outro verbete influente nessa relação é comunhão (koinonia), que aparece visível ou subjacente. A koinonia é o aspecto identitário da vida cristã, que une a comunidade e transforma a paróquia em "rede de comunidades". Finalmente, o objetivo próximo da conversão pastoral da Nova Paróquia é a acolhida e missão (evangelização), citado também na listagem vista acima. O ser cristão pressupõe itinerância, o conteúdo da mensagem pascal é algo a ser levado e revelado ao mundo. "É oportuno que nos eduquemos para peregrinar, inclusive nos desertos e espaços inéditos. Vivemos um processo de releitura criativa do nosso secular patrimônio espiritual, ao mesmo tempo em que descobrimos novas modalidades de profetismo e inserção no mundo hodierno" ${ }^{42}$. Nessa nova perspectiva, ficam relativizadas as antigas categorias de territorialidade (já que na WEB/Internet e na Comunicação as fronteiras se diluem), $o$ atendimento religioso tende para o personalismo e a desburocratização das funções paroquiais (caso da secretaria paroquial) ${ }^{43}$, e a própria pastoral sacramental avança de uma realidade puramente pragmática ("receber o sacramento") para uma nova moção celebrativa ("viver, celebrar os sacramentos").

A Nova Paróquia é "Comunidade de Comunidades" (Doc. 100) de "Discípulos-Missionários" (DAp) que anunciam e vivem a "Alegria do Evangelho" (EG). Esse axioma revela a identidade e missão da Nova Paróquia onde tudo é renovado: sua estrutura/autocompreensão espacial, seus sujeitos e ministérios, sua postura, pedagogia e linguagem, sua relação com a sociedade e as pessoas. É a "Velha Paróquia" que, para "nascer de novo", volta ao seio (ventre) da Comunidade: "Trata-se de um novo modo de autoconsiderar-se, em gestação na comunidade. Uma nova maneira de o Povo de Deus conceber-se em seu ser e no seu agir. Uma autoconsciência que, naturalmente, provoca um sentimento novo e inspira uma nova prática" ${ }^{44}$. O que permanece como critério e sentido da Nova Paróquia é Jesus Cristo, suas palavras e obras, seu

${ }^{42}$ MAÇANEIRO, Marcial. "Espiritualidade cristã: cinco palavras para o nosso tempo". Teologia em Questão 16 (2009), p. 112.

${ }^{43}$ CNBB, Documento 100, n. 38-48.

${ }^{44}$ ANDRADE, Djalma Rodrigues de. Reinventar a paróquia? Sonhar em tempo de incerteza. São Paulo: Loyola, 2006, p. 39. 
sacrifício e salvação (cristocentrismo). Justamente porque a Paróquia é Corpo que compartilha sua vida com a Cabeça (Caput) que é Cristo.

\section{A inserção das Novas Comunidades (NC) na pluralidade missionária}

O apelo a uma Igreja missionária é um fato irreversível. Neste momento eclesial, o Papa Francisco revela seu profundo desejo de uma Igreja que saia da sua estrutura cômoda, e assuma com coragem esta tarefa, alcançando especialmente as periferias, que precisam da luz do Evangelho. Como afirmou diversas vezes o Papa Francisco, as fronteiras e periferias não são apenas geográficas, mas também simbólicas ${ }^{45}$.

Recorda Francisco que a opção pela ação missionária é um imperativo que vem do ser cristão e que as estruturas da instituição paroquial são impelidas a uma conversão, transformando-se em estruturas missionárias, demonstrando sua capacidade e possibilidade de reinventar-se. De acordo com a docilidade e a criatividade do pastor e da comunidade é possível responder a esse desafio que se apresenta, abrindo-se especialmente a novas integrações, superando a ideia acomodada de que as coisas estão boas como estão, ou as rotinas que impedem a criatividade própria de quem é aberto ao Espírito ${ }^{46}$. Neste sentido, a riqueza e a beleza dos NME terá sentido quando houver envolvimento com as paróquias para o enriquecimento da Igreja "em saída":

As outras instituições eclesiais, comunidades de base e pequenas comunidades, movimentos e outras formas de associação são uma riqueza da Igreja que o Espírito suscita para evangelizar todos os ambientes e setores. Frequentemente, trazem um novo ardor evangelizador e uma capacidade de diálogo com o mundo que renovam a Igreja. No entanto, é muito salutar que não percam o contato com esta realidade muito rica da paróquia local e que se integrem de bom grado na pastoral orgânica da Igreja particular. Essa integração evitará que fiquem só com uma parte do Evangelho e da Igreja, ou que se transformem em nômades sem raízes ${ }^{47}$.

${ }^{45}$ SPADARO, Antonio S.J. “¡Despiertenal Mundo! Diálogo del Papa Francisco sobre la vida religiosa”. La Civiltá Cattolica I (2014), p. 13.

${ }^{46}$ FRANCISCO. Evangelii Gaudium, n. 20.

${ }^{47}$ Idem, 29. 
É preciso ultrapassar definitivamente, onde há, o conflito hierarquia/ laicato: todos são inteiramente membros do povo de Deus; o que vem primeiro é o ser cristão. A cada empenho na direção da superação de uma possível divisão, ganharão tanto a atividade missionária como a Palavra do Evangelho, que chegará, onde se faz mais urgente e necessária, pela unidade de forças entre leigos e hierarquia, NME/NC e paróquias. Eis, portanto, o desafio: a integração pastoral entre as NC e NME e a paróquia/diocese. Como escreve Brighenti: "Desafia-se a renovação da paróquia em comunidades menores, para dar acolhida a outras formas comunitárias de viver a fé. Desafio ainda maior é colocar os "movimentos" eclesiais dentro da comunidade e da Igreja local"

É importante que essa união de forças se visibilize em uma instância paroquial fundamental de Comunhão e Participação: o CPP (Conselho de Pastoral Paroquial). Na Paróquia, todas as forças autônomas (Religiosos, Consagrados, Membros de Sociedades de Vida Apostólica e de Associações Privadas de Fiéis) encontrem no CPP uma raiz que as coloca fincadas lado a lado no mesmo compromisso missionário: "in any of those circumstances they might also be members of the parish pastoral council" (em qualquer uma dessas circunstâncias inserindo também como membros do Conselho de Pastoral Paroquial) ${ }^{49}$.

Os NME, explica o Documento de Aparecida, são espaços onde os fiéis podem se formar cristãmente, crescer e comprometer-se apostolicamente até serem verdadeiros discípulos missionários ${ }^{50}$. Assim exercitam o direito batismal de livre associação, como indicou o Concílio Vaticano II e o confirma o Código de Direito Canônico ${ }^{51}$. Muitos fiéis retornaram ou se aproximaram da Igreja através deles. Se a Igreja convoca à missão e é próprio da missão atingir os que estão afastados ou que nunca se aproximaram de nenhuma comunidade religiosa, observando com respeito as atividades realizadas pelos NME e NC, considerando e avaliando como uma boa razão para avanço da integração entre paróquias e NME/NC.

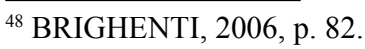

${ }^{49}$ SWEENY, Edward A. The Obligations and Rights of the Pastor of a Parish: According to The Code of Canon Law. New York: St. Pauls, 2002, p. 165.

${ }^{50}$ CELAM, 2008, p. 200.

51 "Os fiéis têm o direito de fundar e dirigir livremente associações para fins de caridade e piedade, ou para favorecer a vocação cristã no mundo (...)”. In: CÓDIGO DE DIREITO CANÔNICO, 1983, cân. 215.
} 
"Todas as formas agregativas de fiéis manifestam um autêntico entusiasmo missionário, de modo que se tornem sujeitos de uma nova evangelização" 52 . Os NME e as NC trazem em si a presença entusiasmada de diferentes estados de vida - homens e mulheres, pessoas solteiras e casadas, clérigos, leigos, religiosos, que, segundo o específico de cada vocação, compartilham a mesma tarefa apostólica. Por trazerem em si uma espiritualidade profunda e sólida, possuem uma disposição que, se canalizada para a pastoral paroquial, farão a atividade missionária da Igreja ganhar.

Levemos em consideração a força formativa e capaz de ajudar os batizados a progredirem na dimensão intelectiva da fé (intellectus fidei) que os NME e as NC possuem. Estas realidades que têm enriquecido a vida da Igreja sempre oferecem a seus membros oportunidade de aprofundamento da vocação batismal, o que os torna potenciais formadores. A lacuna existente, em algumas paróquias, no que se refere à formação e à catequese permanente dos batizados, não ocorre na vida dos NME e NC. Ao contrário, em muitos desses Movimentos e Comunidades a formação e a espiritualidade são pilares essenciais para os que se tornam seus membros.

É fundamental, porém, como recorda o Documento de Aparecida, respeitar seu carisma e originalidade para melhor aproveitá-los, levando-os a integrarem-se mais plenamente na vida da Diocese ou Paróquia. Devem os NME e NC ter real unidade com a Igreja Particular e a Paróquia, não só de fé, mas de ação. Haja então entre os pastores discernimento espiritual suficiente para favorecer a necessária integração dos movimentos na vida diocesana e paroquial, apreciando a riqueza de sua experiência comunitária, formativa e missionária. Os NME que já passaram pelo reconhecimento e discernimento da Santa Sé, sejam olhados com especial atenção, sendo considerados como dons e bens para a Igreja Universal ${ }^{53}$.

A figura abaixo (Figura 1) ilustra a dinâmica integradora entre a Paróquia/Diocese e os NME/NC de acordo com o Documento de Aparecida:

${ }^{52}$ FERREIRA, 2011, pp. 94-96.

${ }^{53}$ CELAM, 2008, p. 143. 
Figura 1: A dinâmica integradora entre Paróquia/Diocese e NME/NC segundo o DAp.

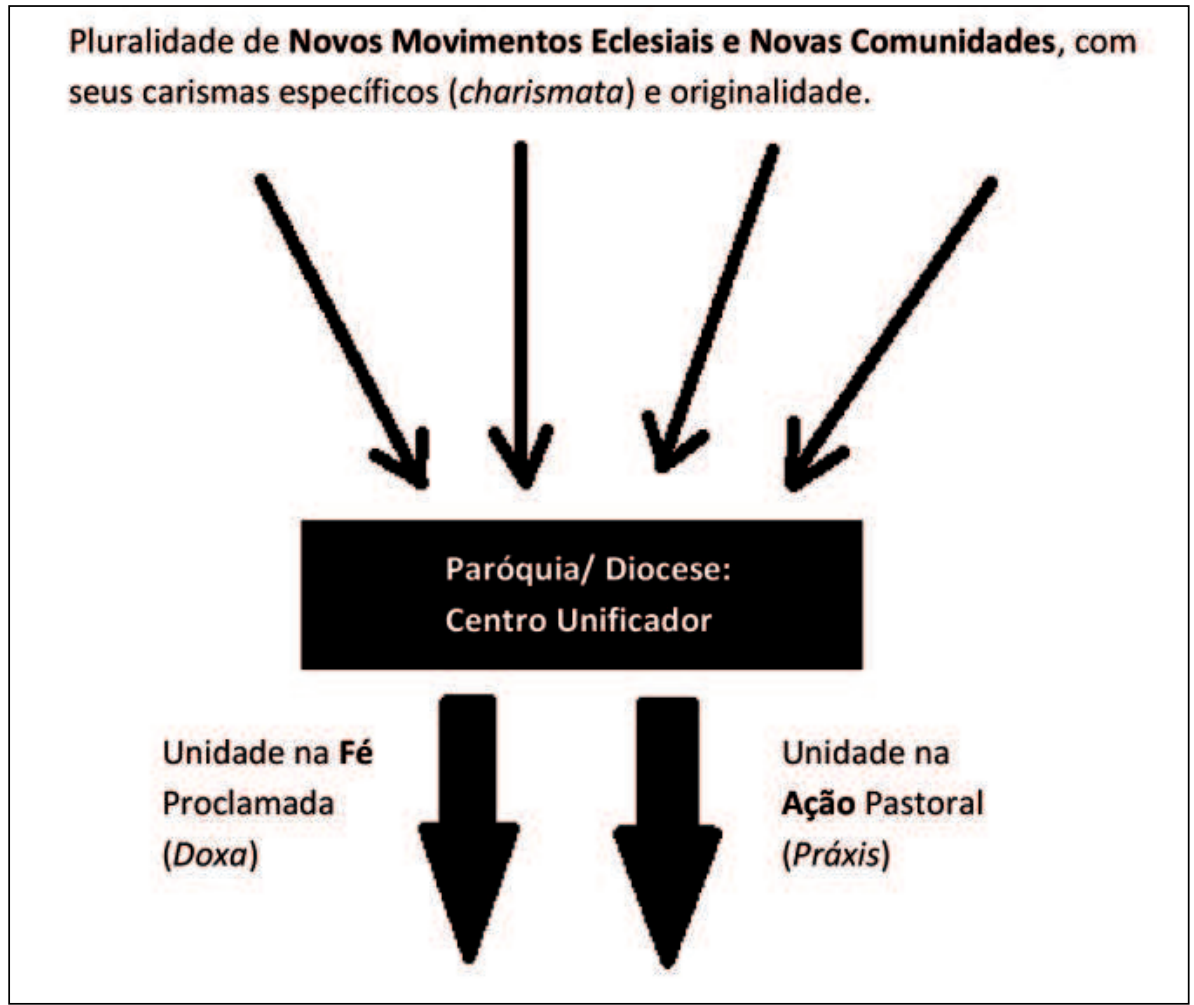

Ora, dessa forma, fica patente que a Paróquia/Diocese é o "Centro Unificador" capaz de integrar as Pastorais com os Movimentos, Comunidades e Associações, para que haja harmonia na Pregação (Sin-fonia) e na Ação (Sin-ergia). Os instrumentos de harmonização são tanto os Formais (Conselhos participativos, bom relacionamento) como os Materiais (Diretrizes, Diretórios e Planos de Pastoral).

Encontramos por aí muitos NME e NC que estão vivendo suas espiritualidades e desenvolvendo suas atividades num caminho autônomo e segmentado. O Documento 100 da CNBB faz o apelo para integrá-los com a finalidade de tornar a paróquia mais rica em serviços, ministérios e testemunho ${ }^{54}$. Aliás, acima se pôde valorizar o aspecto da riqueza formativa dos

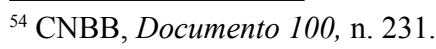


membros dos NME e das NC. O testemunho é outro aspecto também destacado no Documento 100; o testemunho de santidade dessas pessoas dá credibilidade ao ensinamento da Igreja. Como afirma Umberto Eco no seu diálogo com o cardeal Martini: "A força de uma ética se julga pelo comportamento dos santos, não pelo dos ignorantes cuius deus venter est"

Uma grande chave integradora ou desagregadora é a Pastoral de Conjunto, como aponta o Documento 100:

O grande desafio, contudo, consiste na vivência da comunhão e na pastoral de conjunto da diocese e das comunidades. Os movimentos e associações de fiéis, por terem organização supra diocesana, muitas vezes, recebem orientações independentes da diocese, e não raras vezes surgem desconfortos nas suas relações com paróquias e comunidades. Tais grupos têm direito de reivindicar sua presença nas dioceses, mas alguns têm receio de que o plano de pastoral lhes prive do carisma específico. Às vezes, alguns planos de pastoral são muito fechados para acolher os movimentos, e, em alguns ambientes, há certo preconceito em relação a eles ${ }^{56}$.

Percebe-se a necessidade de iniciativas em duas direções em vista do diálogo, das renúncias mútuas e da abertura ao outro. A primeira direção chama a Igreja local a valorizar as riquezas das NC e NME, agregando a si e deixando de ser um entrave para missão evangelizadora. As Diretrizes e Planos de Pastoral podem ser "Cartas Magnas" de integração pastoral, de forma que, quanto mais claras tais orientações pastorais forem, mais harmônica e organizada será a ação pastoral ${ }^{57}$. A segunda direção exige que as $\mathrm{NC}$ e NME tenham uma postura de diálogo interno entre os próprios membros, principalmente seus superiores, sobre questões externas que envolvem a vida da Igreja local e as necessidades da paróquia onde estão localizados. Apenas os membros das NC e NME que comungam do mesmo carisma e projeto de vida podem abrir e solucionar questões de integração com as realidades pastorais externas para uma boa resolução. Se a paróquia interferir diretamente nessas instâncias internas das NC e NME, isso gera mal-estar e até mesmo rejeição, comprometendo o nível afetivo das relações interpessoais e consequentemente, a missão evangelizadora.

${ }^{55}$ ECO, Umberto; MARTINI, Carlos Maria. En que creen los que no creen: Un diálogo sobre la ética em El fin Del milenio. Trad. de Carlos Gumpert Melgosa. Buenos Aires: Editorial Planeta Argentina, 1998, p. 26.

${ }^{56} \mathrm{CNBB}$, Documento 100, n. 233.

${ }^{57}$ Idem, n. 234. 
Deste modo, pergunta-se: como as NC e NME podem integrar suas próprias diretrizes com as paroquiais/diocesanas? Se a Igreja local estiver aberta a acolher esta realidade eclesial, este desafio cabe, primariamente, aos líderes e Conselhos que governam as NC e NME. Se os líderes não aceitarem essa integração com as Dioceses/Paróquias, os membros serão induzidos a não concretizarem essa integração também.

O caminho é o da integração e da comunhão. É urgente superar a rivalidade na evangelização entre duas estruturas diferentes (NME e NC de um lado, a tradicional paróquia de outro). A estrutura canalizadora por excelência é a paróquia. As NC e NME não podem se colocar no mesmo plano das comunidades paroquiais, como possíveis alternativas, mas sim servir a essa célula original e plural do Povo de Deus ${ }^{58}$. E “(...) é nesse serviço que é dado na estrutura paroquial ou diocesana que se revelará a validade das respectivas experiências no interior dos movimentos e associações." ${ }^{59}$ Movimentos e associações de fiéis não podem alimentar pretensões de totalidade. De outra parte, a paróquia não tem direito de excluir ou negar a existência de movimentos e associações que expressam a multiforme graça de Deus com seus dons e carismas entre os leigos ${ }^{60}$.

Por fim, compreende-se que a integração é feita em esferas concêntricas que se alargam: a integração dos NME e NC com a Paróquia e a Diocese leva à integração dos mesmos com a sociedade, culminando naquela "íntima união entre a Igreja e a família humana" ${ }^{61}$ retratada na Gaudium et Spes. Como escreve Brighenti: "Só verdadeiras comunidades podem contribuir na construção de uma sociedade solidária" ${ }^{2}$.

\section{Conclusão}

A dimensão missionária é ampla, especialmente no que se refere a chegar àqueles que estão nas periferias existenciais (afastados da vida comunitária); o engajamento dos agentes que atualmente temos em ação nas pastorais não é suficiente para tantos apelos, porém existem coisas muito bonitas acontecendo por toda parte na Igreja e em alguns casos não integrada, diminuindo a eficiência da ação pastoral e evangelizadora nas paróquias e dioceses.

\footnotetext{
${ }^{58}$ CNBB, Documento 100, n.235.

${ }^{59}$ Idem.

${ }^{60}$ Idem.

${ }^{61}$ CONCÍLIO VATICANO II. Constituição Pastoral Gaudium et Spes, n. 1.

${ }^{62}$ BRIGHENTI, 2006, p. 83.
} 
Os NME e as NC são um fato eclesial que a Igreja tem olhado com olhar materno e também com admiração. Eles agregam muito às igrejas locais, sobretudo pelo testemunho de vida de seus membros e a boa formação sobre os conteúdos da fé que eles possuem (intellectus fidei). Existe muita vida e energia nos NME e NC para se gastar e dispor na atividade pastoral paroquial e diocesana se houver uma aproximação, diálogo, formação, organização e planejamento.

Reconhecer o que ambos têm (paróquias/dioceses e NME/NC) de deficiências e potencialidades e somar organizadamente as forças só traria maior riqueza para as comunidades e a evangelização. No que tange às Paróquias e Dioceses, citamos alguns caminhos para a integração entre as Paróquias/ Dioceses e as NC/NME: instâncias Formais como os Conselhos Paroquiais (CPP) e Diocesanos de Pastoral (CPD), estreitamento dos relacionamentos, e instâncias Materiais como Diretórios e Diretrizes que integrem todas as realidades, resultando numa harmonia na práxis (prática) e na doxa (pregação).

No que tange às NC e NME, um primeiro caminho para a integração é a conciliação hermética de duas realidades que lhe fazem apelo: as Diretrizes e necessidades internas (referentes ao Carisma) e as Diretrizes e necessidades externas (referentes à proposta diocesana/paroquial). As lideranças e Conselhos diretores das NC e NME precisam buscar, justamente nesse "processo fechado" (por isso hermético), resolver essas questões com discernimento e boa vontade.

\section{Referências bibliográficas}

ALMEIDA, Antônio José de. Leigos em quê? Uma abordagem histórica. São Paulo, Paulinas, 2006.

ANDRADE, Djalma Rodrigues de. Reinventar a paróquia? Sonhar em tempo de incerteza. São Paulo: Loyola, 2006.

BALTHASAR, Hans Urs von. Teologia de la Historia. Trad. de José Maria Valverde. 2 ed. Madrid: Ed. Guadarrama, 1964.

BRIGHENTI, Agenor. A pastoral dá o que pensar: a inteligência da prática transformadora da fé. Manual Básico de Teologia Pastoral. São Paulo: Paulinas, 2006.

CAMISASCA, Massimo; VITALI, Maurizio. I movimenti nella Chiesa negli anni' 80. Atti del $1^{\circ}$ Convegno Internazionale (Roma, 23-27 settembre 1981). Milano: Jaca Book, 1982. 
CÓDIGO DE DIREITO CANÔNICO. Vaticano: Libreria Editrice Vaticana, 1983.

CONCÍLIO VATICANO II. Decreto Apostolicam Actuositatem. Vaticano: Librería Editrice Vaticana, 1965.

CONCÍLIO VATICANO II. Constituição Pastoral Gaudium et Spes. Vaticano: Librería Editrice Vaticana, 1965.

CONGAR, Yves M.-J. El Espíritu Santo. Barcelona: Herder, 1991.

CNBB. Comunidade de Comunidades: uma Nova Paróquia. Documento 100. Brasília: Edições CNBB, 2014.

DANIEL, Yvan; GODIN, Henri. La France, pays de mission? Lyon: Les Éditions de l'Abeille, 1943.

ECO, Umberto; MARTINI, Carlos Maria. En que creen los que no creen: Un diálogo sobre la ética em el fin del milenio. Trad. de Carlos Gumpert Melgosa. Buenos Aires: Editorial Planeta Argentina, 1998.

FERNANDEZ, José Cobo (Org.). A presença da Igreja na cidade II: Novos desafios, novas abordagens. Petrópolis: Vozes, 1997.

FERREIRA, Wagner. As Novas Comunidades no Contexto Sociocultural Contemporâneo. São Paulo: Canção Nova, 2011.

FLORISTÁN, Casiano. Para compreender La Parroquia. Estella: Editorial Verbo Divino, 1998.

FORTE, Bruno. As Cores do Amor. Trad. de Silva Debetto C. Reis. São Paulo: Loyola, 2013.

FRANCISCO, Exortação Apostólica Evangelii Gaudium. Vaticano: Libreria Editrice Vaticana, 2013.

GUERREIRA, Julio A. Ramos. Teología Pastoral. Serie de Manuales de Teología "Sapientia Fidei". Madrid: Biblioteca de Autores Cristianos, 1995.

JOÃO XXIII. Carta Encíclica Princeps Pastorum. Vaticano: Libreria Editrice Vaticana, 1959.

JOÃO PAULO II. Exortação Apostólica Pós-Sinodal Chritifideles Laici. Vaticano: Libreria Editrice Vaticana, 1988.

LE GOFF, Jacques. O apogeu da Cidade Medieval. Trad. de Antônio de Pádua Danesi. São Paulo: Martins Fontes, 1992. 
MAÇANEIRO, Marcial. "Espiritualidade cristã: cinco palavras para o nosso tempo". Teologia em Questão 16 (2009).

MAÇANEIRO, Marcial. "Missão no Plural”. Teologia em Questão 18 (2010).

PAGOLA, José Antonio. Acción pastoral para una nueva evangelización. Santander: Sal Terrae, 1991.

PAULO VI. Exortação Apostólica Evangelii Nuntiandi. Vaticano: Libreria Editrice Vaticana, 1975.

SOUZA, Cirlene Cristina de. "Cidade-gente: desafios para a missão da Pastoral Urbana”. Teologia em Questão 18 (2010).

SPADARO, Antonio S.J. “¡Despiertenal Mundo! Diálogo del Papa Francisco sobre la vida religiosa”. La Civiltá Cattolica I (2014).

SWEENY, Edward A. The Obligations and Rights of the Pastor of a Parish: According to The Code of Canon Law. New York: St. Pauls, 2002.

SZENTMÁRTONI, Mihály. Introdução à Teologia Pastoral. Trad. de Orlando Soares Moreira. 3 ed. São Paulo: Loyola, 2014.

CELAM. Documento de Aparecida. Trad. de Luiz Alexandre Solano Rossi. 5 ed. São Paulo: Paulus, 2008.

Denilson Geraldo

Doutor em Direito Canônico pela Pontifícia Universidade Lateranense de Roma Professor no Programa de Pós-Graduação em Teologia da PUC-SP

São Paulo / SP - Brasil e-mail: denil.ge@gmail.com

Rodrigo Fernando Alves

Mestrando no Programa de Pós-Graduação em Teologia da PUC-SP

São Paulo / SP - Brasil e-mail: rodrigofernando26@hotmail.com

Recebido em: 30/06/15

Aprovado em: 15/09/15 
